\title{
Presentació. ArqueoPyrenae 2, un espai de reflexió amb futur
}

\author{
Jordi Morera Camprubí ${ }^{1}$, Joan Oller Guzmán ${ }^{1}$, Oriol Olesti Vila ${ }^{1}$
}

L'any 2016, gràcies a la col-laboració entre l'Ajuntament de Bolvir de Cerdanya i l'àrea d'Història Antiga de la Universitat Autònoma de Barcelona, vàrem iniciar els col-loquis ArqueoPyrenae, que tenien per objectiu fomentar la recerca històrica $\mathrm{i}$ arqueològica a les terres pirinenques $\mathrm{i}$ contribuir a la valorització del seu patrimoni cultural. Aquell primer col.loqui, dedicat a l'explotació dels recursos naturals al Pirineu oriental en època antiga, va ser publicat el 2017, fet que va constituir una veritable referència per a tots aquells equips, que, establerts a banda i banda de la serralada, no sempre tenien la possibilitat de reunir-se i contrastar els seus mètodes i resultats de manera pràctica $\mathrm{i}$ efectiva. Poder disposar d'un centre com l'Espai Ceretània i la generositat de l'Ajuntament de Bolvir van fer-ho possible. La voluntat de l'equip organitzador era continuar amb aquestes reunions, així que, malgrat la dolorosa pèrdua del nostre amic Oriol Mercadal aquell mateix any i la recent pandèmia del Covid-19 que hem hagut de superar, ara veu la llum el segon volum d'aquests encontres. Es tracta del segon col-loqui ArqueoPyrenae, celebrat de nou a l'Espai Ceretània entre els dies 19 i 20 d'octubre del 2018, amb una àmplia participació de més de 40 ponents $i$ assistents. La voluntat de l'anterior alcalde de Bolvir, Bartomeu Baqué, així com la de l'actual, Isidre Chia, han fet possible celebrar i publicar aquesta reunió, i permeten garantir-ne la continuïtat. El Pirineu necessita generar espais de reflexió i de recerca, fets des del territori i per al territori, però amb voluntat d'estendre's més enllà. Això ha estat, i seguirà sent, l'objectiu dels Arqueopyrenae.

El tema d'aquest ArqueoPyrenae 2, «Els Pirineus en el marc de la Segona Guerra Púnica (218-202 a.n.e.): Territori de pas i de contacte», és fàcil d'argumentar. Fa quasi 40 anys, el 1982, es va celebrar el 5è Col-loqui internacional d'Arqueologia de Puigcerdà, dedicat precisament al pas d'Anníbal pel Pirineu. La seva publicació fou una fita per als estudis pirinencs, però al mateix temps mostrava les limitacions dels treballs arqueològics desenvolupats fins aquell moment en aquestes contrades. Quasi quatre dècades després la situació és molt diferent. En els darrers anys diversos equips que treballen en l'àmbit català i del Sud de França estan posant de manifest la petjada arqueològica d'aquest esdeveniment bèl.lic. Des de l'arribada de les tropes púniques després de la conquesta de Sagunt (219 a.n.e.) fins als enfrontaments amb els pobles indígenes comencem a tenir indicis arqueològics d'aquesta presència, així com de la posterior contraofensiva romana. Aquest col.loqui ha reunit els diversos equips implicats en l'estudi d'aquest període, amb especial atenció a les terres pirinenques i

1. Universitat Autònoma de Barcelona. Àrea d'Història Antiga. Departament de Ciències de l'Antiguitat i l'Edat Mitjana. Arqueòlegs.cat. jordi.morera@uab.cat; joan.oller@uab.cat; oriol.olesti@uab.cat 
prepirinenques, zona de pas de l'exèrcit d'Anníbal segons les fonts literàries. Tanmateix, però, també s'han tingut en compte altres territoris afectats, com la vall del Guadalquivir o els mateixos Alps. En total, han participat a la reunió un conjunt de 12 equips, cosa que ha donat lloc a una síntesi final d'11 articles, tots ells revisats i avaluats per dos experts externs, seguint les normes del procés de revisió de peer-review.

Preteníem amb aquest nou ArqueoPyrenae establir un panorama comú en l'estudi dels territoris, jaciments, materials arqueològics i numismàtics d'aquest període, analitzant el procés de domini i transformació de les societats indígenes que s'inicià l'any 218 a.n.e., sempre tenint en compte les seves múltiples dinàmiques regionals. Creiem, amb modèstia però sense dubtar-ho, que aquesta fita s'ha assolit abastament. Esperem que tots els lectors d'aquests treballs puguin estar-hi d'acord.

Bellaterra-Bolvir, desembre de 2020 . 